\title{
Permissive nicotine regulation as a complement to traditional tobacco control Walton Sumner II*
}

\author{
Address: Department of Medicine, Washington University School of Medicine, St. Louis, Missouri, USA \\ Email: Walton Sumner* - wsumner@im.wustl.edu \\ * Corresponding author
}

Published: 24 February 2005

BMC Public Health 2005, 5:18 doi:10.1 I86/147I-2458-5-18
Received: 24 August 2004

Accepted: 24 February 2005

This article is available from: http://www.biomedcentral.com/I47/-2458/5//8

(C) 2005 Sumner; licensee BioMed Central Ltd.

This is an Open Access article distributed under the terms of the Creative Commons Attribution License (http://creativecommons.org/licenses/by/2.0), which permits unrestricted use, distribution, and reproduction in any medium, provided the original work is properly cited.

\begin{abstract}
Background: Cigarette smoking takes a staggering toll on human health and attracts considerable public health attention, yet real solutions seem distant. The 2004 Family Smoking Prevention and Tobacco Control Act (US Senate bill S246I) would have given the US Food and Drug Administration limited authority to regulate cigarettes to "protect the public health." However, such legislation is unlikely to substantially reduce smoking or related deaths.
\end{abstract}

Discussion: The past 500 years of tobacco control efforts demonstrate that nicotine prohibition is a practical impossibility for numerous reasons, state revenue being one of the most ominous. The FDA already has regulatory authority over pharmaceutical grade nicotine products, and requires pharmacists to dispense the most addictive of these only with prescriptions. Meanwhile, every corner store can sell far more addictive and dangerous cigarettes to any adult. The FDA could immediately increase competition between cigarettes and clean nicotine products by approving available nicotine products for over-the-counter sales to adults. Similarly permissive regulation of cigarettes and addictive nicotine products will reduce tobacco use and improve smokers' health, but increase nicotine use in the population. Fortunately, restricted youth access and accurate labeling of nicotine's absolute risks will dissuade many non-smokers from experimenting with it, while accurate depiction of its risks relative to cigarette smoking will encourage many smokers to switch. The FDA could take a series of small steps that might ultimately replace a large proportion of cigarette smoking with equally addictive nicotine products, without risking serious public health setbacks. Vaccine, methadone, and injury prevention policies establish relevant public health precedents.

Summary: Cigarettes, or an equally addictive alternative, will be a permanent and common product in most societies. Regulations restricting only the safest addictive nicotine products are hard to justify. Addictive nicotine compliments other tobacco control strategies. Modern tobacco control policies are applicable to addictive nicotine. Controlled trials and test market studies are urgently needed to evaluate addictive nicotine as an alternative to smoking. Meanwhile, legislators should preserve the Food and Drug Administration's option to permit non-prescription sales of addictive nicotine. 


\section{Background}

Cigarette smoking is a source of worldwide misery $[1,2]$ and revenue for corporations and governments. Landmark tobacco regulatory efforts in the United States include the 1992 Synar Amendment, requiring States to establish and enforce prohibitions on the sale and distribution of tobacco products to persons under 18 years of age [3]. The 1998 Master Settlement Agreement (MSA) prohibited numerous marketing practices, especially those likely to entice youth [4]. The six corporate signatories also promised an endless series of payments to the settling States, currently $\$ 8$ billion annually. The United States has endorsed the World Health Organizations' 2003 Framework Convention on Tobacco Control (FCTC) [5]. The FCTC enumerates well-studied, politically safe measures such as taxation; limiting youth access; regulating the content, packaging, advertising, and sales of tobacco products; and educating the public about risks. Fire-safe cigarettes [6] are now required in New York. Several states and many municipalities now require smokefree workplaces.

The recently defeated [7] 2004 Family Smoking Prevention and Tobacco Control Act, S2461 [8], would have established Food and Drug Administration (FDA) regulation of cigarettes for the first time. Although average citizens could easily have taken "FDA regulation" to suggest the extensive power that the FDA holds over pharmaceutical products[9], tobacco regulations would have been weaker. The defeated Act sought publication of brand-specific ingredient information; forbade adding children's favorite flavorings to cigarettes, further restricted teen sales and advertising; and allowed the FDA to regulate cigarettes' nicotine delivery. The FDA would not have been able to ban or eliminate nicotine from cigarettes, nor could the FDA ban a class of tobacco products. Although modestly effective at preventing and ending tobacco use, such measures will not achieve the Healthy People 2010 (HP2010) goal of $12 \%$ adult smoking prevalence [10] on schedule [11], if ever. While cigarettes should never again afflict more than a quarter of the United States population, tobacco regulation will abate the current level of carnage only very slowly.

A complimentary strategy called "harm reduction" proposes that smokers could improve their health by frequently substituting less hazardous tobacco products, such as 'smokeless cigarettes,' chewing tobacco, and newer smokeless tobacco products for cigarettes [12-14]. 'Smokeless cigarettes' are neither smokeless nor cigarettes, but complicated devices that release a mixture of chemicals from a heated tobacco substrate and can emit more carbon monoxide than a cigarette [15-18]. For individuals who are determined to inhale nicotine, these devices are probably no worse than cigarettes. However, for individu- als who would have quit instead of switching to a smokeless cigarette, the health cost may be large. The Institute of Medicine has called for extensive research to quantify harms and patterns of use of these "potential reduced exposure products" (PREP) [19]. In contrast, chewing tobacco is clearly safer than smoking cigarettes $[20,21]$, exposing users to as little as $2 \%$ of the risks of smoking [22]. The newest smokeless tobacco products are discrete enough to use in almost any social setting. Smokeless tobacco products are much less popular than smoking in the United States for a variety of reasons, including restrictions on advertising. However, the most important limitation of smokeless tobacco may be absorption through the nicotine through systemic veins rather than the pulmonary vasculature. All current pharmaceutical nicotine products share this limitation.

Some tobacco control advocates suggest a third strategy: national policies encouraging competition between safer nicotine products and cigarettes [20,23-34]. Typically, this involves a "level playing field" with similar regulations for pharmaceutical grade nicotine delivery systems and cigarettes. Advocates cite evidence that health risk correlates with exposure to tobacco's combustion and curing byproducts [35-38], with nicotine replacement products posing the least risk $[39,40]$.

There are different ways to level this playing field. At one extreme, the FDA could increase regulation of cigarettes to match that of nicotine products. This is politically challenging, as the FDA discovered in the 1990's [41], The Family Smoking Prevention and Tobacco Control Act divided both the tobacco industry and the public health community. Altria, corporate parent of Philip Morris, was the only tobacco company to endorse this legislation. Calling a similar bill the "Marlboro monopoly act" [42], critics suspect that Altria hoped to discourage competition, for instance by encumbering smaller producers with regulations, by prohibiting relative safety claims sought by chewing tobacco manufacturers [43], or by discouraging new products with stringent new standards $[44,45]$. Other critics believe that the Act safeguarded certain cigarette marketing and legal defense strategies [9], or paved the way for the company's unproven 'smokeless cigarettes,' potentially ushering in another generation of suffering.

At another extreme, the FDA could regulate other nicotine products more permissively, as cigarettes have been regulated. The FDA has that authority, but would face criticism for facilitating a common addiction. For instance, the FDA could approve non-prescription nicotine nasal sprays and slow acting inhalers for indefinite use by adults. These nicotine replacement therapies have excellent safety records and low potential for addicting non-smokers, although a 
few ex-smokers become addicted. The widespread misconception that nicotine prohibition is practical and desirable makes it politically difficult for the FDA to pursue this path.

\section{Discussion \\ Problems with nicotine prohibition}

A recent Lancet editorial called for the criminalization of tobacco products [46]. However, a litany of centuries-old problems with prohibition provides a strong argument for permissive nicotine regulation as an alternative or essential prerequisite to prohibition. Many people will pay high prices to a coalition of suppliers and governments to obtain tobacco cigarettes that efficiently deliver nicotine, a drug perceived to provide some benefits, in spite of substantial immediate and long-term risks of smoking. While comprehensive public smoking restrictions are possible, and some companies may exit the tobacco trade, traditional tobacco control and litigation may not provide additional large public health gains in the United States, and prohibition is a practical impossibility.

The first problem is that historically, smokers accept personal and public hazards that make the dangers we associate with tobacco look quaint. After Christopher Columbus failed to control his crew's tobacco use, monarchs from England to China tried to contain the weed by execution, disfigurement, exile, and onerous taxation [47]. Tobacco trade drained monarchs' wealth, compromising national security, and smoking accidents incinerated whole cities. Tobacco use spread anyway.

The second problem is that risk-tolerant smokers are no small group. Smoking persists where Mormon and Islamic prohibitions discourage it $[48,49]$. If $70 \%$ of smokers in the USA want to quit [50]. then $30 \%$ of smokers, more than $6 \%$ of the adult population, do not want to quit.

The third problem is a common genetic predisposition to nicotine addiction [51]. The modifiable risk factors we associate with smoking initiation and persistence - parent behavior, peer pressure, role models, advertising, accessibility, repeated exposure, and perceived norms - were irrelevant to Christopher Columbus' crew and the first tobacco users across Eurasia. Risk factor modification will not alter genetically predisposed users' fascination with their first tobacco products.

The fourth problem is that so much money is involved. When state and local taxes raised New York City cigarette prices to US $\$ 7$ per pack, tax revenues and black marketing both increased [52]. During the invasion of Iraq, stressed US soldiers reportedly paid up to US $\$ 50$ per pack [53]. The black market for tobacco in Colorado prisons may achieve a 45,000\% markup [54]. This industry makes large profits selling a simple product. If liability claims bankrupt corrupt companies, new suppliers will fill the void and try to avoid predecessor's mistakes. Black markets will undermine the benefits of high taxation or prohibition.

The fifth problem is that government taxation compromises tobacco control efforts. Historically, States willingly trade citizens' health for wealth. Seventeenth century monarchs who opposed smoking relented as tobacco tax revenue accumulated. The States demonstrated the same perverse values with petitions to protect their MSA payments when an Illinois court threatened Altria with a US $\$ 12$ billion bond [55]. The States will predictably protect the MSA corporate signatories from new competitors, for instance with taxes targeting generic brands. Tax revenues diminish prospects for even slowing the growth of tobacco sales in Africa, Eurasia, and South America, and prohibition in those areas is currently impossible.

The sixth problem is the lack of a popular mandate for prohibition. Tobacco control advocates in the United States are rightfully pleased with smoking's declining prevalence, reduced teen smoking, rising cigarette prices, spreading restrictions on public smoking, and fire-safe cigarette initiatives. However, none of this demonstrates popular support for prohibition. Citizens will balk at limiting the supposedly personal choice to smoke in private. Midwesterners have already rejected modest cigarette tax hikes [56]. Furthermore, most taxes and MSA payments subsidize programs that benefit non-smokers [57]. Prohibition would eliminate that subsidy and require nonsmokers to pay for enforcement, a very unlikely prospect.

The seventh problem is that nicotine use could have a favorable risk-benefit profile for some informed users. Nicotine causes a mild euphoria without intoxication, in contrast to more tightly regulated drugs: it does not destroy relationships as intoxicating drugs routinely do. Many smokers may use nicotine to treat various problems [58-60] including depression [61], attention deficits [62], other mental illness [63], symptomatic systemic diseases [64], or to control weight [65]. Nicotine users may perform some tasks better, especially those involving vigilance and rapid visual cue processing $[66,67]$. There is uncertainty regarding many of these benefits [68]. Nevertheless, expected benefits are politically hard to withhold. If some of these benefits are real, nicotine prohibition may not even be desirable.

Nicotine accounts for very few of the long-term hazards of smoking. A smokeless tobacco proponent has likened nicotine's risks to the risks of consuming caffeine [54]. Fetal exposure causes placental constriction and reduced birth 
size, alters brain development in disturbing ways, and may increase susceptibility to later nicotine addiction [6976]. Nicotine might contribute to sudden infant death syndrome [69,77-79], destruction of connective tissue [80], modulation of immune function [81], prevention of apoptosis $[82,83]$, and alcohol or other substance abuse [84-86]. Fatal nicotine poisoning is quite unlikely [8789]. Given that smokeless tobacco users experience only about $2 \%$ of the risks of smoking [22], and that inhaled nicotine is similarly benign in animal models [90-92], it is very unlikely that inhaled nicotine could account for even one-tenth of the harms of smoking.

In summary, however desirable tobacco prohibition may be, it is hopelessly impractical - unless smokers, governments, and producers have an equally satisfying alternative.

\section{Stifling innovation}

Legal and regulatory pressures have prevented the development of meaningful alternatives to cigarettes. Directed to approve drugs as "safe and effective" for specific indications, and to ignore tobacco, the FDA has had little reason to approve chronic, addictive nicotine. Although the FDA approves more dangerous drugs for specified indications, without an indication there is no benefit to weigh against any nicotine risk. Consequently the FDA requires prescriptions for slow acting inhalers and nasal spray because of a small risk of inconsequential addiction in ex-smokers. Unfortunately, seemingly risk averse regulation of nicotine forces public health policies to rely on difficult smoking prevention, cessation, use restrictions, and treatment. The net effect is a risky public health policy, and very slow development of new nicotine delivery systems [32]. Another unfortunate side effect has been that companies put tobacco into any device that they do not want regu- lated, particularly, 'smokeless cigarettes,' even if the device would be safer without tobacco. In permissive nicotine regulation, the FDA's missing indication is to improve nicotine addicts' safety. As prescription methadone substitutes for illegal, immediately incapacitating heroin, nonprescription nicotine could substitute for legal, slowly injurious cigarettes.

Tort threats have also delayed product improvement efforts within the industry. In 1963 an industry lawyer, anticipating condemnation in the 1964 Surgeon General's report, suggested competing on safe nicotine delivery, but was overruled [93]. Product liability and regulatory issues pushed tobacco companies into pointless projects including filters, light cigarettes, "smokeless cigarettes", nicotine-free cigarettes, and fabricating a controversy over the health risks of smoking.

\section{Haddon matrix}

In the mid 1960's, motor vehicle accidents were also taking a terrific health toll in the United States. While alternatives to driving existed, no one expected private automobiles to disappear. Instead, systematic efforts transformed traffic safety. Haddon's matrix illustrated how complimentary strategies could work together to reduce the morbidity and mortality of driving [94]. Table 1 shows a matrix with two axes representing time and objects. Most injury control efforts fall into one of the nine cells, although some cells are empty. Before an accident, typical preventive efforts remove or modify unsafe drivers, vehicles, and road conditions. During an accident a vehicle's design and environmental safeguards may prevent or limit injuries. After an accident, prompt medical attention limits the morbidity and mortality of the injuries that still occur.

Table I: Haddon's Matrix for Reducing Traffic Accident Injuries

\begin{tabular}{|c|c|c|c|}
\hline & Driver/Passenger & Vehicle & Environment \\
\hline Before Accident & $\begin{array}{c}\text { Licensing } \\
\text { Stops, tickets, arrests } \\
\text { Drug, alcohol screening } \\
\text { Physician advice }\end{array}$ & $\begin{array}{l}\text { Running lights } \\
\text { Antilock brakes } \\
\text { High traction tires } \\
\text { Vehicle inspections } \\
\text { Impact avoidance }\end{array}$ & $\begin{array}{c}\text { Road design } \\
\text { Road maintenance } \\
\text { Road lighting, marking } \\
\text { Traffic law } \\
\text { Police patrols }\end{array}$ \\
\hline During Accident & ---- & $\begin{array}{l}\text { Bumpers } \\
\text { Seat belts } \\
\text { Airbags } \\
\text { Crumple zones } \\
\text { Fuel containment }\end{array}$ & $\begin{array}{c}\text { Deformable barriers } \\
\text { Fences }\end{array}$ \\
\hline After Accident & ---- & Fuel containment & $\begin{array}{l}\text { Telecommunications } \\
\text { Emergency stabilization } \\
\text { Emergency transport } \\
\text { Trauma centers }\end{array}$ \\
\hline
\end{tabular}


Table 2: Haddon's matrix adapted to tobacco control

\begin{tabular}{|c|c|c|c|}
\hline & Potential user & Nicotine delivery device & Environment \\
\hline Before Addiction & $\begin{array}{l}\text { Addiction education } \\
\text { Disease education } \\
\text { Counter-advertising }\end{array}$ & $\begin{array}{l}\text { Warning labels } \\
\text { Labeling regulations }\end{array}$ & $\begin{array}{c}\text { Youth sales restrictions } \\
\text { Taxation } \\
\text { Black market policing } \\
\text { Prohibition }\end{array}$ \\
\hline During Use & $\begin{array}{c}\text { Disease education } \\
\text { Cessation advertising } \\
\text { Bupropion } \\
\text { Nortiptylline } \\
\text { Varenicline [105], } \\
\text { Rimonabant [97] }\end{array}$ & $\begin{array}{c}\text { Filters } \\
\text { Low tar cigarettes } \\
\text { Smokeless tobacco } \\
\text { Smokeless cigarettes } \\
\text { Content regulation } \\
\text { Nicotine replacement } \\
\text { Addictive inhalers }\end{array}$ & $\begin{array}{l}\text { Taxation } \\
\text { Prohibition }\end{array}$ \\
\hline After Injury & $\begin{array}{l}\text { Disease awareness } \\
\text { Cessation advice }\end{array}$ & $\begin{array}{l}\text { Nicotine replacement } \\
\text { Addictive inhalers }\end{array}$ & $\begin{array}{c}\text { Disease screening } \\
\text { Disease treatment } \\
\text { Cures }\end{array}$ \\
\hline
\end{tabular}

For tobacco control, smoking replaces accidents as the focal event (Table 2 - anticipated strategies are italicized) [95]. As with accidents, cells contain only partially effective interventions. Many people experiment with tobacco in spite of efforts to prevent tobacco use. During smoking, smokers quit infrequently in spite of warnings and medications. More effective smoking cessation products may appear $[96,97]$. but some nicotine use will persist. In the center cell, hazardous cigarettes easily dominate all available nicotine replacement products [98]. Available and anticipated harm reduction products may be safer, but addictive nicotine would be safer still. After injury, detection of disease may be slow, and treatments for tobaccorelated diseases are seldom curative. The matrix highlights the problems of incomplete prevention, unsafe nicotine sources, and poor treatment options, and demonstrates why permissive nicotine regulation could benefit public health: when prevention fails, results are bad. Making nicotine addiction as safe as possible would make prevention failures less disastrous.

\section{Proposal}

For the reasons outlined above, the health benefits of addictive pharmaceutical grade nicotine products would likely outweigh the harms. If so, the FDA could improve public health by regulating nicotine much as the government has regulated cigarettes.

A permissive nicotine regulatory policy would allow sales of pharmaceutical grade nicotine delivery systems to adults without a prescription. The FDA could suggest warnings appropriate for classes of products and delivery system constituents. Manufacturers would accurately label contents, and would be legally liable for undisclosed harms caused by the delivery system and constituents other than nicotine, as with any pharmaceutical product. The FDA could prohibit inherently risky delivery systems, and would undertake a full, traditional review of nicotine systems that give users a faster or higher peak arterial level of nicotine than cigarettes. The FDA would also review additives intended to provide antidepressant or other effects familiar to smokers $[99,100]$. Youth marketing and access would be illegal, as with cigarettes. The Drug Enforcement Agency would have no jurisdiction over non-intoxicating nicotine products, just as it has no interest in tobacco. Most public and workplace restrictions on cigarette smoking would be irrelevant to other nicotine delivery systems.

States could tax cigarettes and nicotine at different rates, in theory recovering expenses related to each product. This tax policy would discourage cigarette use, encourage switching to nicotine, and maintain some State revenue as cigarette sales decline. A satisfying, safe, legal, and affordable alternative to cigarettes would discourage black markets. The FDA and Federal Trade Commission could permit advertising of nicotine as an alternative to smoking, and monitor relative harm claims. Nicotine manufacturers would pay for monitoring of adverse health effects from their products until remaining health questions are answered.

The FDA could implement a permissive policy in a series of simple, informative steps. First, the FDA could immediately approve non-prescription sales of the existing nicotine spray and inhaler, and similar competitors, with restraints consistent with the Synar amendment, the MSA, and the FCTC. In particular, it should require disclosure of known nicotine risks, such as addiction, invite comparisons to smoking risks, and forbid marketing to minors. 
Data collected during this first step will inform subsequent steps. Economists have shown that the price of nicotine gum and patches affects demand for cigarettes [101]. This means that some smokers will substitute less expensive but very slow acting nicotine replacement products for cigarettes. Non-prescription access to more addictive and competitively priced nicotine should increase this substitution, especially if addicts can purchase a one day supply of about $20 \mathrm{mg}$. Clinical trials and post-marketing studies of non-prescription use of the spray and inhaler would begin to answer questions about nicotine and pregnancy, substance abuse, and heart disease. Surveillance studies would determine whether clean nicotine options lead more people to smoke, to smoke longer, or to use nicotine during pregnancy. While the Institute of Medicine recommends years or decades of study to quantify the risks of "smokeless cigarettes", the most important remaining uncertainties about nicotine might be answered in a few years. Data collected during this first step should document the relative safety of addiction to pharmaceutical nicotine versus cigarettes, the market share of each product, and the increase in total nicotine use. Analyses using these data will predict the consequences of more permissive regulation [102].

If experience with the current nicotine spray and inhaler is reassuring, the FDA can take a second step, to approve clearly addictive nicotine inhalers for non-prescription use. These fast acting inhalers will deliver nicotine in a powder [103] or aerosol to the alveoli, as pulmonary inhalers deliver steroids and beta agonists. Fast acting nicotine inhalers would be subject to the same marketing requirements and surveillance described above.

Several trends could develop that encourage smokers to switch to addictive nicotine inhalers, while limiting recruitment of non-smokers. Smokers will appreciate the healthier alternative to cigarettes, especially as they develop smoking related illnesses, while warning labels will discourage casual experimentation by non-smokers. Smoke-free workplace regulations would spread with less controversy, as fast acting inhalers give smokers a reasonable alternative. Employers might voluntarily forbid smoking to reduce health care and workman's compensation costs; reduce workplace fires; and increase productivity by eliminating both smoking breaks and withdrawal symptoms. Physicians might strongly encourage smokers to switch for their own health, primarily, but also for the health of family members. The government might permit more aggressive advertising of nicotine inhalers to further undermine cigarette smoking. Governments will probably find nicotine taxation irresistible, especially if their tobacco revenue declines. Nicotine taxation will raise the cost of experimenting with inhalers beyond some teenager's means. Communities might press smokers to switch so that fire departments, health care providers, and research funding agencies could shift resources to many other pressing problems. Ultimately, palatable inhaled nicotine products could finally allow governments to ban tobacco cigarettes.

The public health benefits of these policy shifts could be substantial. We can estimate the long term relative public health burdens of different policies as the product of the risks posed by a delivery system, relative to cigarettes, and the fraction of the adult population using it. Using this formula, the current burden is more than $20 \%$ use $\times 100 \%$ risk $=0.2$. Healthy People 2010 calls for $12 \%$ use $\times 100 \%$ risk $=0.12$, about half of the current burden. If nicotine accounted for a surprising $10 \%$ of smoking risks, eliminating smoking by quintupling the prevalence of inhaled nicotine use - universal addiction - would cause 100\% use $\times 10 \%$ risk $=0.1$, a slight improvement over HP2010. A slightly less pessimistic scenario would be that all past and present smokers become inhaled nicotine addicts, but their risk is only twice that of smokeless tobacco users. This scenario is no more than $70 \%$ use $\times 4 \%$ risk $=0.028$, about a quarter of the HP2010 burden. The most likely scenario is that nicotine risks are about $2 \%$ of smoking risks, and that policy changes will slowly shift the probabilities that smokers will attempt and succeed in quitting, that smokers will switch to nicotine indefinitely or use both nicotine and cigarettes, that ex-smokers relapse to nicotine use, and that non-smokers begin using nicotine. If the risks of inhaled nicotine are this low and if at least one smoker can switch to addictive inhaled nicotine for every 50 ex-smokers and non-smokers who start using nicotine, then public health will benefit from permissive nicotine regulation. One public health risk is that more people might begin or continue smoking cigarettes in the belief that inhaled nicotine will provide an easy escape path, but suffer irreparable harm before switching. We should quantify these probabilities through surveillance of the public's behavior and health consequences following each step toward more permissive nicotine regulation.

Although S2461 was defeated, the continuing carnage will motivate similar legislative proposals. Tobacco policies must preserve the possibility of permissive nicotine regulation. Bad legislation could solidify the position of cigarettes, delay safer products, prohibit disclosure of relative harms, or otherwise interfere with market forces that ought to benefit nicotine addicts [104]. The FDA must retain the option to unleash real competition against a disastrous status quo in the tobacco industry.

\section{Summary}

Nicotine use will remain common indefinitely. Pharmaceutical grade nicotine is the safest known substance that could replace cigarettes, but inherently addictive products 
are required to compliment traditional tobacco control policies effectively. The FDA could apply restrictions, similar to those on cigarettes, to an increasingly addictive portfolio of nicotine products, requiring honest portrayals of absolute and relative risks, and expect a significant reduction in cigarette smoking and related illness with modest recruitment of new nicotine addicts at each step. A brief and focused research effort could solidify the already substantial justification for such permissive nicotine regulation. Meanwhile, federal legislation must not obstruct free market ideals of competitive innovation and informed consumption.

\section{Competing interests}

The author(s) declares that he has no competing interests.

\section{References}

I. Cigarette smoking-attributable morbidity---United States, 2000. MMWR Morb Mortal Wkly Rep 2003, 52:842-844.

2. Ezzati M, Lopez AD: Estimates of global mortality attributable to smoking in 2000. Lancet 2003, 362:847-852.

3. Synar Amendment. Public Health Service Act [42 USC § 300x26(b)(2)] 1992.

4. Master Settlement Agreement [http://www.attorneygen eral.gov/ppd/tobacco/pdf/msa.pdf]

5. WHO Framework Convention on Tobacco Control FCTC [http://www.who.int/tobacco/framework/download/en/]

6. Philip Morris USA To Launch New Cigarette Paper Nationwide On All Merit Cigarettes [http://www.philipmorrisusa.com/ pressroom/content/press release/articles/ pr july 122000 pmutlncpnoamc.asp]

7. Altria Group and Philip Morris USA Express Great Disappointment on the Lack of FDA Regulation in the FSC/ETI Tax Bill [http://www.philipmorrisusa.com/pressroom/content/ press release/articles/

PR October II 2004 AGAPMUEGDOTLOFRITFTB.asp]

8. To protect the public health by providing the Food and Drug Administration with certain authority to regulate tobacco products. 108th Congress, 2nd Session2004.

9. Siegel M: Michael Siegel's FDA Fact Sheet II. [http:// www.smokefree.net/bg-announce/messages/247/18.html].

10. Healthy People 20 10: January 2000; Washington, D.C.. (Conference Edition, in two volumes) edition. U.S. Department of Health and Human Services.; 2000.

11. Mendez D, Warner KE: Smoking prevalence in 2010: why the healthy people goal is unattainable. Am J Public Health 2000, 90:40I-403

12. Gori GB: Low-risk cigarettes: a prescription. Science 1976, 194: 1243-1246.

13. Can tobacco cure smoking? A review of tobacco harm reduction. In Committee on Energy and Commerce 108th Congress edition. Washington, DC, US Government Printing Office; 2003.

14. Henningfield JE, Moolchan ET, Zeller M: Regulatory strategies to reduce tobacco addiction in youth. Tob Control 2003, I 2 Suppl I:I I4-124.

15. Bowman DL, Smith CJ, Bombick BR, Avalos JT, Davis RA, Morgan WT, Doolittle DJ: Relationship between FTC 'tar' and urine mutagenicity in smokers of tobacco-burning or Eclipse cigarettes. Mutat Res 2002, 52 I:137-149.

16. Stapleton JA, Russell MA, Sutherland G, Feyerabend C: Nicotine availability from Eclipse tobacco-heating cigarette. Psychopharmacology (Berl) 1998, 139:288-290.

17. Thun MJ, Glynn TJ: Health consequences of eclipse cigarettes. Jama 2000, 284:2995-2996.

18. O'Connell V: As 'Safer Smokes' Multiply, States Probe Marketing Claims. Wall Street Journal 2004:I,10.

19. Institute of Medicine: Clearing the smoke: Assessing the Science Base for Tobacco Harm Reduction. Edited by: Stratton K SPWRBS. Washington, D.C., National Academy Press; 2001.
20. Bates C, Fagerstrom K, Jarvis MJ, Kunze M, McNeill A, Ramstrom L: European Union policy on smokeless tobacco: a statement in favour of evidence based regulation for public health. Tob Control 2003, I 2:360-367.

21. Rodu B, Jansson C: Smokeless tobacco and oral cancer: a review of the risks and determinants. Crit Rev Oral Biol Med 2004, 15:252-263.

22. Vigneswaran N, Tilashalski K, Rodu B, Cole P: Tobacco use and cancer. A reappraisal. Oral Surg Oral Med Oral Pathol Oral Radiol Endod 1995, 80: 1 78-182.

23. Russell MA: The future of nicotine replacement. Br J Addict |991, 86:653-658.

24. Koop CE, Kessler DA: Final report of the Advisory Committee on Tobacco Policy and Public Health. Tob Control 1997, 6:254-26I.

25. Warner KE, Slade J, Sweanor DT: The emerging market for longterm nicotine maintenance. Jama 1997, 278:1087-1092.

26. Warner KE, Peck CC, Woosley RL, Henningfield JE, Slade J: Treatment of tobacco dependence: innovative regulatory approaches to reduce death and disease: preface. Food Drug Law J 1998, 53: I-8.

27. Henningfield JE, Slade J: Tobacco-dependence medications: public health and regulatory issues. Food Drug Law J 1998, 53:75-I I 4.

28. Page JA: Federal regulation of tobacco products and products that treat tobacco dependence: are the playing fields level? Food Drug Law J 1998, 53: I I-42.

29. Slade J, Henningfield JE: Tobacco product regulation: context and issues. Food Drug Law J 1998, 53:43-74.

30. Sweanor D: Regulatory imbalance between medicinal and non-medicinal nicotine. Addiction 2000, 95:S25-S28.

31. Kozlowski LT, Strasser AA, Giovino GA, Erickson PA, Terza JV: Applying the risk/use equilibrium: use medicinal nicotine now for harm reduction. Tobacco Control 200I, 10:20I-203.

32. McNeil A, Foulds J, Bates C: Regulation of nicotine replacement therapies (NRT): a critique of current practice. Addiction 200I, 96:1757-1768.

33. Warner KE: Tobacco harm reduction: promise and perils. Nicotine Tob Res 2002, 4 Suppl 2:S6I-7I.

34. Crane J, Blakely T, Hill S: Time for major roadworks on the tobacco road? New Zealand Medical Journal 2004, I I 7:

35. Foulds J, Ramstrom L, Burke M, Fagerstrom K: Effect of smokeless tobacco (snus) on smoking and public health in Sweden. Tob Control 2003, I 2:349-359.

36. Leistikow BN, Martin DC, Samuels SJ: Injury death excesses in smokers: a 1990-95 United States national cohort study. Inj Prev 2000, 6:277-280.

37. Heishman SJ, Balfour DJ, Benowitz NL, Hatsukami DK, Lindstrom JM, Ockene JK: Society for Research on Nicotine and Tobacco. Addiction 1997, 92:615-633.

38. Rodu B: An alternative approach to smoking control. Am J Med Sci 1994, 308:32-34.

39. Murray RP, Bailey WC, Daniels K, Bjornson WM, Kurnow K, Connett JE, Nides MA, Kiley JP: Safety of nicotine polacrilex gum used by 3,094 participants in the Lung Health Study. Lung Health Study Research Group. Chest 1996, 109:438-445.

40. Murray RP, Daniels K: Long-Term Nicotine Therapy. In Nicotine safety and toxicity Edited by: Benowitz . New York (NY), Oxford University Press; 1998: 173-182.

4I. Pulling Out All The Stops: Philip Morris' Fight to Block FDA Regulation of Tobacco [http://www.infact.org/fdarept.html]

42. Berlau J: Smoking Out Big Tobacco. [http://www.insight mag.com/news/552374.html].

43. Gierer VA: Annual Report 2002. , UST Inc; 2002:3.

44. Cummings KM: Michael Cummings on FDA legislation. [http:// www.smokefree.net/bg-announce/messages/247/32.html].

45. Siegel M: Michael Siegel's FDA Fact Sheet V. Serious Problems with the Modified Risk Product section of S246 I: Why it Will Not Protect the Public's Health [http://www.smokefree.net/bg-announce/mes sages/247I27.html].

46. How do you sleep at night, Mr Blair? Lancet 2003, 362:1865.

47. Kluger R: Ashes to ashes. New York, Alfred A. Knopf; 1996:8-16.

48. Prevalence of Current Cigarette Smoking Among Adults and Changes in Prevalence of Current and Some Day Smoking - United States, 1996-200I. MMWR Morb Mortal Wkly Rep 2003, 52:303-307. 
49. Shafey O, Dolwick S, Guindon GE: Tobacco Control Country Profiles 2003. Atlanta, GA, American Cancer Society; 2003.

50. Trosclair A, Husten C, Pederson L, Dhillon I: Cigarette smoking among adults, United States, 2000. MMWR 2002, 5 I:642-645.

5I. Madden PA, Heath AC, Pedersen NL, Kaprio J, Koskenvuo MJ, Martin NG: The genetics of smoking persistence in men and women: a multicultural study. Behav Genet I999, 29:423-43I.

52. Fairclough G: Pssst! Wanna cheap smoke? Wall Street Journal 2002:1.

53. Phillips MM: Craving nicotine, Skittles deep inside Iraq. Wall Street Journal 2003:I

54. Rodu B: California, Cigarettes and Prisons: Ban smoking, not tobacco. [http://www.reviewjournal.com/lvri home/2004/Feb-05Thu-2004/opinion/23134395.html].

55. Fairclough G, O-Connell V: Co-Dependents: Once tobacco foes, States are hooked on settlement cash. Wall Street Journal 2003:1.

56. Bell B: Defeat of tax hike on tobacco shows voters distrust, expert says. In Post Dispatch Five Star Lift edition. St. Louis, ; 2002:CI.

57. Tobacco Settlement: States' Use of Master Settlement Agreement Payments. , United States General Accounting Office 200I.

58. Benowitz NL: Pharmacology of nicotine: addiction and therapeutics. Annu Rev Pharmacol Toxicol 1996, 36:597-6I3.

59. Baron JA: Beneficial effects of nicotine and cigarette smoking the real, the possible and the spurious. Br Med Bull 1996, 52:58-73.

60. Lerman C, Caporaso N, Main D, Audrain J, Boyd NR, Bowman ED, Shields PG: Depression and self-medication with nicotine: the modifying influence of the dopamine D4 receptor gene. Health Psychol 1998, I7:56-62.

61. Whalen CK, Jamner LD, Henker B, Gehricke JG, King PS: Is there a link between adolescent cigarette smoking and pharmacotherapy for ADHD? Psychol Addict Behav 2003, 17:332-335.

62. Leonard S, Adler LE, Benhammou K, Berger R, Breese CR, Drebing C, Gault J, Lee MJ, Logel J, Olincy A, Ross RG, Stevens K, Sullivan B, Vianzon R, Virnich DE, Waldo M, Walton K, Freedman R: Smoking and mental illness. Pharmacol Biochem Behav 200I, 70:56I-570.

63. Sandborn WJ, Tremaine WJ, Offord KP, Lawson GM, Petersen BT, Batts KP, Croghan IT, Dale LC, Schroeder DR, Hurt RD: Transdermal nicotine for mildly to moderately active ulcerative colitis. A randomized, double-blind, placebo-controlled trial. Ann Intern Med 1997, I 26:364-37I.

64. Waldron I: Patterns and causes of gender differences in smoking. Soc Sci Med 1991, 32:989-1005.

65. Stough C, Mangan G, Bates T, Pellett O: Smoking and Raven IQ. Psychopharmacology (Berl) 1994, I l6:382-384.

66. Mancuso G, Warburton DM, Melen M, Sherwood N, Tirelli E: Selective effects of nicotine on attentional processes. Psychopharmacology (Berl) 1999, 146: 199-204.

67. Parrott AC: Cigarette-derived nicotine is not a medicine. World I Biol Psychiatry 2003, 4:49-55.

68. Dempsey DA, Benowitz NL: Risks and benefits of nicotine to aid smoking cessation in pregnancy. Drug Saf 200I, 24:277-322.

69. Ernst M, Moolchan ET, Robinson ML: Behavioral and neural consequences of prenatal exposure to nicotine. J Am Acad Child Adolesc Psychiatry 200I, 40:630-64I.

70. Ellis L, Cole-Harding S: The effects of prenatal stress, and of prenatal alcohol and nicotine exposure, on human sexual orientation. Physiol Behav 200I, 74:2I 3-226.

7I. Cornelius MD, Leech SL, Goldschmidt L, Day NL: Prenatal tobacco exposure: is it a risk factor for early tobacco experimentation? Nicotine Tob Res 2000, 2:45-52.

72. Slotkin TA: Fetal nicotine or cocaine exposure: which one is worse? J Pharmacol Exp Ther 1998, 285:931-945.

73. Lambers DS, Clark KE: The maternal and fetal physiologic effects of nicotine. Semin Perinatol 1996, 20: I I5-126.

74. Frydman M: The smoking addiction of pregnant women and the consequences on their offspring's intellectual development. J Environ Pathol Toxicol Oncol 1996, I5:169- I72.

75. Ellard GA, Johnstone FD, Prescott RJ, Ji-Xian W, Jian-Hua M: Smoking during pregnancy: the dose dependence of birthweight deficits. Br J Obstet Gynaecol 1996, 103:806-8| 3 .

76. Slotkin TA: The Impact of Fetal Nicotine Exposure on Nervous System Development and its Role in Suddent Infant
Death Syndrome. In Nicotine safety and toxicity Edited by: Benowitz New York (NY), Oxford University Press; 1998:89-97.

77. Sayers NM, Drucker DB, Telford DR, Morris JA: Effects of nicotine on bacterial toxins associated with cot death. Arch Dis Child 1995, 73:549-55I.

78. Milerad J, Sundell H: Nicotine exposure and the risk of SIDS. Acta Paediatr Suppl 1993, 82 Suppl 389:70-72.

79. Murphy EA, Danna-Lopes D, Sarfati I, Rao SK, Cohen JR: Nicotinestimulated elastase activity release by neutrophils in patients with abdominal aortic aneurysms. Ann Vasc Surg 1998, 1 2:4I-45.

80. McAllister-Sistilli CG, Caggiula AR, Knopf S, Rose CA, Miller AL, Donny EC: The effects of nicotine on the immune system. Psychoneuroendocrinology 1998, 23:175-187.

81. Onoda N, Nehmi A, Weiner D, Mujumdar S, Christen R, Los G: Nicotine affects the signaling of the death pathway, reducing the response of head and neck cancer cell lines to DNA damaging agents. Head Neck 200I, 23:860-870.

82. Wright SC, Zhong J, Zheng H, Larrick JW: Nicotine inhibition of apoptosis suggests a role in tumor promotion. Faseb J 1993, 7:|045-|05|

83. Henningfield JE, Clayton R, Pollin W: Involvement of tobacco in alcoholism and illicit drug use. $\mathrm{Br}$ J Addict 1990, 85:279-291.

84. Madden PA, Heath AC, Starmer GA, Whitfield JB, Martin NG: Alcohol sensitivity and smoking history in men and women. Alcohol Clin Exp Res 1995, 19: I I I- I I20.

85. Narahashi T, Soderpalm B, Ericson M, Olausson P, Engel JA, Zhang X, Nordberg A, Marszalec W, Aistrup GL, Schmidt LG, Kalouti U, Smolka, Hedlund L: Mechanisms of alcohol-nicotine interactions: alcoholics versus smokers. Alcohol Clin Exp Res 200I, 25:I52S-I56S.

86. Hipke ME: Green tobacco sickness. South Med J 1993, 86:989-992.

87. Ballard T, Ehlers J, Freund E, Auslander M, Brandt V, Halperin W: Green tobacco sickness: occupational nicotine poisoning in tobacco workers. Arch Environ Health 1995, 50:384-389.

88. Woolf A, Burkhart K, Caraccio T, Litovitz T: Self-poisoning among adults using multiple transdermal nicotine patches. I Toxicol Clin Toxicol 1996, 34:691-698

89. Waldum HL, Nilsen OG, Nilsen T, Rorvik H, Syversen V, Sanvik AK, Haugen OA, Torp SH, Brenna E: Long-term effects of inhaled nicotine. Life Sci 1996, 58:1339-1346.

90. Syversen U, Nordsletten L, Falch JA, Madsen JE, Nilsen OG, Waldum HL: Effect of lifelong nicotine inhalation on bone mass and mechanical properties in female rat femurs. Calcif Tissue Int 1999, 65:246-249.

91. Loennechen JP, Nilsen OG, Arbo I, Aadahl P, Nilsen T, Waldum HL, Sandvik AK, Ellingsen O: Chronic exposure to carbon monoxide and nicotine: endothelin ET(A) receptor antagonism attenuates carbon monoxide-induced myocardial hypertrophy in rat. Toxicol Appl Pharmacol 2002, I78:8-14

92. Hilts PJ: Smokescreen: The truth behind the tobacco industry cover-up. Reading, Massachusetts, Addison-Wesley Publishing Company, Inc; 1996:30-37.

93. Haddon WJ: A logical framework for categorizing highway safety phenomena and activity. J Trauma 1972, 12:193-207.

94. Runyan CW: Introduction: back to the future--revisiting Haddon's conceptualization of injury epidemiology and prevention. Epidemiol Rev 2003, 25:60-64.

95. Sands S, Reeves K. Ending an Addiction., Pfizer, Inc. 2002:9.

96. Fernandez JR, Allison DB: Rimonabant Sanofi-Synthelabo. Curr Opin Investig Drugs 2004, 5:430-435.

97. Pierce JP, Gilpin EA: Impact of over-the-counter sales on effectiveness of pharmaceutical aids for smoking cessation. Jama 2002, 288: $1260-1264$

98. Berlin I, Aubin HJ, Pedarriosse AM, Rames A, Lancrenon S, Lagrue G: Lazabemide, a selective, reversible monoamine oxidase B inhibitor, as an aid to smoking cessation. Addiction 2002, 97: 1347-1354.

99. Rommelspacher H, Meier-Henco M, Smolka M, Kloft C: The levels of norharman are high enough after smoking to affect monoamineoxidase B in platelets. Eur J Pharmacol 2002, 44I: II $5-125$

100. Tauras JA, Chaloupka FJ: The demand for nicotine replacement therapies. Nicotine Tob Res 2003, 5:237-243.

10I. Sumner W: Estimating the health consequences of replacing cigarettes with nicotine inhalers. Tob Control 2003, I 2: 124-132. 
102. Rose JE, Behm F, Turner J: Dry powder delivery system. USA, Duke University (Durham, NC); Advanced Therapeutic Products (San Antonio, TX); 1995.

103. Kozlowski LT, O'Connor RJ, Quinio Edwards B: Some practical points on harm reduction: what to tell your lawmaker and what to tell your brother about Swedish snus. Tob Control 2003, I 2:372-373.

104. Foulds J, Burke M, Steinberg M, Williams JM, Ziedonis DM: Advances in pharmacotherapy for tobacco dependence. Expert Opin Emerg Drugs 2004, 9:39-53.

\section{Pre-publication history}

The pre-publication history for this paper can be accessed here:

http://www.biomedcentral.com/1471-2458/5/18/prepub
Publish with Biomed Central and every scientist can read your work free of charge

"BioMed Central will be the most significant development for disseminating the results of biomedical research in our lifetime. " Sir Paul Nurse, Cancer Research UK

Your research papers will be:

- available free of charge to the entire biomedical community

- peer reviewed and published immediately upon acceptance

- cited in PubMed and archived on PubMed Central

- yours - you keep the copyright

Submit your manuscript here:

http://www.biomedcentral.com/info/publishing_adv.asp 